\title{
Suksesi Kepemimpinan Nasional Secara Selektif Berjenjang: Solusi Permasalahan Sistem Pemilihan Umum di Indonesia
}

\author{
Afnan Fuadia,1* \\ ${ }^{a B a l a i}$ Diklat Aparatur Kementerian Kelautan dan Perikanan \\ 1'afnanfuadi@yahoo.co.id \\ *korespondensi penulis
}

Naskah diterima: 18-02-2019, direvisi: 07-03-2019, disetujui: 25-03-2019

DOI: http://dx.doi.org/10.32493/jpkn.v6i1.y2019.p1-12

\begin{abstract}
Abstrak
Berbagai kelemahan dan persoalan muncul dalam sistem pemilihan umum yang berlaku di Indonesia saat ini, mulai dari partisipasi politik berbiaya tinggi hingga lemahnya sistem kaderisasi kepemimpinan. Artikel ini menghadirkan solusi atas persoalan tersebut melalui sebuah mekanisme suksesi kepemimpinan nasional secara selektif berjenjang dari tingkat rukun tetangga (RT) sampai presiden. Studi menggunakan metode kajian pustaka dengan fokus pembahasan pada; 1) pemilihan pemimpin dengan mengembalikan prinsip musyawarah mufakat sebagai ciri demokrasi pancasila; 2) berlangsungnya kaderisasi para pemimpin melalui sistem selektif berjenjang; dan 3) pembahasan proses implementasi suksesi kepemimpinan dari jenjang paling bawah sampai jenjang paling tinggi. Melalui konsep suksesi kepemimpinan yang baru, biaya politik yang mahal menjadi relatif murah, meminimalisir timbulnya perilaku koruptif, pemimpin yang terpilih memiliki track record yang jelas, serta menghindarkan dari perpecahan dan konflik sosial.
\end{abstract}

Kata-kata kunci: suksesi kepemimpinan; kepemimpinan nasional; sistem pemilihan umum

\section{Abstract}

A variety of weaknesses and problems arise in the current electoral system, including high-cost political participation as well as weak leadership regeneration system. This article presents a solution to the problem through a new mechanism of leadership succession from the lowest level (neighborhood association) to the highest level (president). A literature review method is used in this study with a focus on; 1) the selection of leader by returning the principle of deliberation and consensus as a feature of Pancasila democracy; 2) the regeneration of leaders through a tiered selective system; and 3) discussion of the process of implementing leadership succession from the lowest to the highest level. Through this new concept of leadership succession, expensive political cost becomes relatively cheap, minimizing the emergence of corrupt behavior, the elected leader has a clear track record and avoid social division and conflict.

Keywords: leadership succession; national leadership; election system 


\section{Pendahuluan}

Sebagai bangsa yang menganut prinsip-prinsip demokrasi, memang suksesi kepemimpinan nasional yang tercatat dalam sejarah pemilihan umum di Indonesia dapat berjalan normal setiap lima tahunnya. Namun, persoalan yang terjadi sampai hari ini adalah bangsa Indonesia belum menemukan mekanisme suksesi kepemimpinan nasional yang ideal untuk keberlangsungan kehidupan kebangsaan dan kenegaraan sebagaimana yang diharapkan oleh rakyat Indonesia.

Hal ini dikarenakan efektifitas kepemimpinan hasil dari pemilihan umum yang diselenggarakan setiap lima tahun sekali oleh bangsa Indonesia belum memberikan kontribusi yang nyata terhadap kemakmuran dan kesejahteraan rakyat. Terdapat banyak kelamahan dan permasalahan yang muncul dalam mekanisme pemilihan umum eksekutif dan legislatif yang berlaku saat ini antara lain:

\section{Partisipasi politik berbiaya tinggi}

Ketua DPR Bambang Soesatyo, mengatakan biaya politik tinggi sudah berjalan sejak lama. "Misalnya, dalam ambang batas Pilkada, diatur harus ada rekomendasi dari Parpol, maka ada harganya (rekomendasi). Bupati minimal 5 miliar, Gubernur 50 miliar." (mediaindonesia.com, 4/12/18). Dana besar juga dibutuhkan untuk membuat spanduk, baliho, hingga kampanye terbuka. Dana besar lain juga dibutuhkan untuk menghadirkan saksi di setiap tempat pemungutan suara (TPS), yakni saksi luar dan saksi dalam.
2. Banyaknya Kepala Daerah terjerat korupsi

Pengamat hukum pidana dari Universitas Trisakti Abdul Fickar Hajar menilai maraknya korupsi kepala daerah terjadi karena mahalnya biaya politik untuk menduduki jabatan tersebut (mediaindonesia.com, 12/6/2018). Peneliti ICW Egi Primayoga menyebut, dalam kurun waktu 14 tahun (20142018), ada 104 kepala daerah yang tersandung kasus korupsi yang saat ini ditangani oleh KPK (www.merdeka.com,16/12/2018).

Data menunjukkan setiap tahun ada peningkatan OTT yang dilakukan KPK. Misalnya, tahun 2016, KPK melakukan 17 kali OTT, kemudian tahun 2017 meningkat menjadi 20 OTT, dan pada pada 2018 meningkat lagi menjadi 30 OTT (nasional.sindonews.com, 3/5/19). Seperti tidak ada kata jera, meskipun hukuman penjara juga sudah diterapkan, tetapi praktik korupsi tetap saja marak. hal tersebut cukup untuk menunjukan pada kita bahwa sebenarnya ada yang salah dengan sistem pemilihan umum saat ini.

\section{Biaya penyelenggaraan pemilu sangat tinggi}

Hajatan demokrasi setiap lima tahun sekali untuk memilih eksekutif dan legislatif Bukan tanpa konsekuensi, penyelenggarakan pemilu adalah sebuah hal yang sangat mahal. Pemerintah mengalokasikan anggaran sebesar Rp. 24,8 triliun untuk penyelenggaraan Pemilu dan Pilpres 2019. Direktur Jenderal Anggaran Kementerian 
Keuangan, Askolani, Menjelaskan, selain anggaran penyelenggaraan Pemilu, pemerintah juga mengalokasian anggaran untuk pengawasan sebesar Rp. 4,85 triliun dan anggaran keamanan dialokasikan sebesar Rp. 3,29 triliun, dan anggaran untuk kegiatan pendukung pemilu Rp. 3,29 triliun (kemenkeu.go.id, 26/3/19).

\section{Memakan banyak korban Jiwa}

Beratnya beban petugas mengawal proses panjang pemilu membuat petugas kelelahan secara fisik dan psikologis, kurang tidur, lupa makan, jatuh sakit bahkan meninggal dunia. Berdasarkan data KPU per Sabtu (4/5/19) pukul 16.00 WIB, jumlah petugas Kelompok Penyelenggara Pemungutan Suara (KPPS) yang meninggal sebanyak 440 orang. Sementara petugas yang sakit 3.788 orang.

Sedangkan dari pihak Panwaslu, Ketua Bawaslu Abhan mengatakan 92 anggota Panwaslu dari sejumlah daerah itu meninggal, sebanyak 398 orang masih rawat inap di rumah sakit, 1.592 rawat jalan, 250 orang mengalami kecelakaan, 14 orang cacat tetap, dan 14 petugas mengalami keguguran. Sementara Mabes Polri mencatat anggotanya yang tewas saat mengamankan Pemilu 2019 hingga 29 April 2019 lalu berjumlah 22 orang (news.detik.com, 4/5/19).

\section{Rentan perpecahan dan konflik sosial}

Lembaga Riset PolMark Indonesia menyebut retaknya kerukunan sosial akibat pemilu nyata adanya. Dalam "Catatan Sejumlah Survei" yang dirilis
PolMark, ada peningkatan potensi rusaknya kerukunan sosial selama 20142017. Potret peningkatan itu didapat dari hasil survei PolMark saat pilpres 2014 dan pilkada DKI Jakarta 2017. (tirto.id, 29/8/18).

Satu tahun menjelang Pilpres 2019, polarisasi politik makin menguat. Masyarakat mulai terbelah menjadi dua kelompok yang saling berhadapan. Perbedaan pilihan politik telah menciptakan gesekan sosial dan perpecahan dalam keluarga-keluarga di Indonesia. Energi KPU, Bawaslu, Polri, serta Politisi amat tersita untuk menangani hoax, ujaran kebencian, dan pencemaran di media sosial.

\section{Maraknya praktik Kecurangan}

Penerapan konsep demokrasi One Man One Vote, memicu para calon untuk memperoleh suara sebanyak-banyaknya dengan cara apapun termasuk kecurangan agar kekuasaan dapat diraih. Salah satunya adalah praktik politik uang (money politics) baik pada saat pemilu Presiden, Gubernur, Bupati, bahkan Pemilihan Kepala Desa. Pemberian biaya transpor, makan minum kepada peserta kampanye yang diperbolehkan juga membuat kesulitan bagi pengawas di lapangan untuk membedakan mana cost politic dan money politic.

Berdasarkan laporan Bawaslu pada 2018, hasil pengawasan pada Pemilihan Kepala Daerah 2018 memperlihatkan adanya indikasi politik uang sebanyak 535 kasus di tahapan kampanye. Adapun pada tahapan masa tenang, ditemukan adanya 35 kasus yang tersebar di 10 provinsi. 
Pada proses pemungutan dan penghitungan suara, terdapat 2 kasus praktik politik uang yang terjadi di satu provinsi dan satu kabupaten (nasional.kompas.com, 27/11/18).

\section{Lemahnya Kaderisasi}

\section{Kepemimpinan}

Pasca-Orde Baru tumbang, praktis Partai politik hari ini dinilai publik belum bisa diandalkan untuk menerapkan konsep kaderisasi kepemimpinan nasional. Peran parpol dalam menjalankan suksesi agenda reformasi lebih banyak mengedepankan orientasi yang bersifat feodal, oligarki, pragmatis dan transaksional.

Sistem feodal tampak lekat dengan kuatnya politik figur, sehingga partai bergerak karena kuatnya sosok tertentu di puncak hierarki otoritas partai. Tradisi oligarki nampak dalam distribusi jabatanjabatan publik saat ini lebih banyak ditentukan oleh segelintir elite, sehingga mekanismenya dari-oleh-dan untuk mereka yang menjadi elite partai berkuasa.

Sampai detik ini sejumlah masalah masih mengidap di tubuh bangsa ini, baik di bidang Politik, hukum dan keamanan. Yang jadi pertanyaan, Kenapa itu semua terjadi ? Banyak faktor yang menjadi sebabnya. Tapi, ada satu faktor fundamental yang menjadikan itu semua terjadi, yaitu kegagalan para elite kita memimpin bangsa ini.

Pepatah Cina mengatakan, "Kesalahan yang tidak dikoreksi, maka kesalahan itu akan menjadi kebenaran". Oleh karena itu rumusan bagaimana sistem suksesi kepemimpinan nasional yang efektif dan efisien sangat diperlukan. Sebuah sistem suksesi kepimpinan nasional yang mampu melahirkan pemimpin-pemimpin yang kompeten serta berintegritas, berbiaya murah, dan memastikan terwujudnya kaderisasi.

Hadirnya kepemimpinan yang demikian ini sangat memungkinkan, apabila bangsa Indonesia benar-benar bersedia menerapkan ideologi nasional Pancasila secara konsekuen, khusunya sila ke IV, Kerakyatan yang dipimpin oleh hikmat kebijaksanaan dalam permusyawaratan perwakilan.

Berangkat dari berbagai kelemahan sistem pemilu yang telah diurai di atas, tulisan ini mencoba untuk menghadirkan solusi melalui konsep sistem suksesi kepemimpinan nasional yang baru. Sebuah mekanisme seleksi kepemimpinan yang berjalan natural, dimulai dari bawah sampai mencapai jenjang karir tertinggi.

Ide dasar tulisan ini diangkat dari buah pikir Aryandi Yogaswara berjudul "Konsep 7 Lapis Langit Pemerintahan" yang di muat halaman kompasiana.com, tanggal 19 Maret 2017. Pada bagian pendahuluan ini, data-data diberikan untuk menguatkan urgensi gagasan. Kemudian, pada bagian pembahasan, dikemukakan landasan-landasan teori dari para ahli. Landasan teori disertakan sebagai pondasi bahwa gagasan yang diangkat relevan secara akademik dan ilmiah. 


\section{Metode}

Kajian kepustakaan digunakan sebagai metode studi. Menurut Pohan dalam Prastowo (2012: 81) penyusunan kajian pustaka bertujuan mengumpulkan data dan informasi ilmiah, berupa teori-teori, metode, atau pendekatan yang pernah berkembang dan telah di dokumentasikan dalam bentuk buku, jurnal, naskah, catatan, rekaman sejarah, dokumendokumen, dan lain-lain yang terdapat di perpustakaan.

Selain itu, informasi yang sesuai dengan topik dari media online dikumpulkan untuk mendukung teori. Bahan pustaka dan informasi yang didapat dibahas secara kritis dan mendalam untuk mendukung gagasan yang diangkat.

\section{Hasil dan Pembahasan}

Secercah harapan perkembangan Demokrasi di Indonesia bergulir pada awal era reformasi, rakyat menyambut dengan gembira, rakyat merasa terbebas dari belenggu pemerintahan Orde Baru. Ada optimisme bangsa ini akan mengalami kemajuan menuju masa depan yang gemilang.

Saat ini perjalanan reformasi telah memasuki usia yang ke 20, ada banyak hal yang dapat disyukuri darinya. Namun demikian di era reformasi ini ternyata juga mucul berbagai persoalan baru. Mantan Ketua Mahkamah Konstitusi Mahfud MD bahkan sepakat jika demokrasi di Indonesia saat ini disebut sebagai demokrasi yang kebablasan (Kompas.com, 06/09/18).

Kita masih melihat bahwa demokrasi yang dijalankan saat ini belum sepenuhnya menerapkan Demokrasi Pancasila. Seperti dalam proses pemilihan umum, bahwa keberadaan warga Negara yang mempunyai kedudukan, hak dan kewajiban yang sama diterjemahkan dengan menerapkan sistem voting "satu orang satu kertas suara”. Mekanisme yang sangat rentan kecurangan dan pembodohan, kualitas diabaikan digantikan dengan kuantitas.

Menurut M. Nu'man Soemantri dalam buku Mata Ajar Kuliah Wajib Umum Pendidikan Kewarganegaraan untuk Perguruan Tinggi, (2016:7), menyebutkan bahwa demokrasi yang dianut Indonesia yaitu Demokrasi yang berdasarkan Pancasila dan UUD 1945.

Secara umum, Profesor Dardji Darmo Diharjo, menyebutkan Demokrasi Pancasila adalah suatu paham demokrasi yang didasarkan pada kepribadian dan falsafah kehidupan bangsa Indonesia yang diwujudkan dalam ketentuan-ketentuan UUD 1945. Kemudian secara lebih spesifik, menurut Kansil, pengertian Demokrasi Pancasila adalah kerakyatan yang dipimpin oleh hikmat kebijaksanaan di dalam permusyawaratan dan perwakilan, yang merupakan sila keempat dari Dasar Negara Pancasila seperti yang tercantum dalam alinea ke 4 Pembukaan UUD 1945.

\section{Memilih Para Pemimpin Berdasarkan Pancasila}

Sebagai negara yang berlandaskan ideologi Pancasila seyognyanya bangsa Indonesia dapat menerapkan secara konsekuen demokrasi Pancasila yang tertuang dalam Sila keempat yakni 
"Kerakyatan yang dipimpin oleh hikmat kebijaksanaan dalam permusyawaratan perwakilan". Menurut Prof. Dardji Darmodiharjo dalam bukunya "Menatap Indonesia, Sebuah Antologi Filsafat Hukum dalam Bingkai Negara Pancasila" menyebutkan pengertian demokrasi Pancasila dalam aspek formal adalah cara pengambilan keputusan yang dicerminkan oleh sila keempat dari Pancaila.

Sila keempat ini memberikan pesan yang sangat jelas bahwa bangsa Indonesia dipimpin oleh seorang memiliki hikmat dan kebijaksanaan yang ditunjuk melalui proses "Musyawarah Mufakat". Perbedaan secara umum demokrasi di Barat dan Demokrasi Pancasila di Indonesia adalah terletak pada permusyawaratan tersebut.

Permusyawaratan adalah sebuah cara yang khas sesuai dengan kepribadian Indonesia dalam hal mencari keputusan yang cocok dengan keinginan rakyat sebagai pemegang kedaulatan. Permusyawaratan artinya mengusahakan keputusan secara bulat, sehingga dicapai hasil mufakat. Apabila pengambilan keputusan secara mufakat tidak bisa tercapai, maka voting menjadi jalan yang terakhir. Demokrasi Pancasila tidak diartikan sebagai adu kekuatan satu kelompok untuk merebut kekuasaan dengan mengalahkan kelompok yang lain.

Demikian juga dalam proses pemilihan pemimpin, musyawarah mufakat ini merupakan suatu prinsip bahwa yang dipilih dapat diterima dan bermanfaat bagi kepentingan semua kelompok dan golongan. Pemimpin adalah sosok yang dipandang memiliki hikmat dan kebijaksanaan. Hikmat artinya seorang yang memiliki kemampuan untuk menerima petunjuk kebenaran dari Tuhan Yang Maha Esa. Sementara kebijksanaan adalah kemampuan untuk mengaktualisasikan hikmat yang dimilikinya dalam melayani sesama. Berdasarkan pengertian yang telah di urai di atas jelaslah bahwa spirit yang ajarkan dalam pancasila, bukanlah memilih pemimpin yang mencalonkan diri sendiri kemudian meminta untuk dipilih padahal belum tentu dirinya memenuhi kriteria layak menjadi pemimpin bangsa.

\section{Seleksi Kepemimpinan Nasional Melalui Sistem Karier Berjenjang}

Sudah menjadi sifat dasar dari manusia pada umumnya untuk menjadi lebih baik, lebih maju dari posisi yang dimiliki pada saat ini. Selain berlandaskan semangat musyawarah mufakat, pemilihan para pemimpin bangsa ini juga perlu mengakomodir peningkatan karier secara berjenjang. Para pemimpin yang berprestasi pada skala tertentu layak diberikan kesempatan untuk mengikuti seleksi ke jenjang kepemimpinan yang lebih tinggi. Peneliti senior dari LIPI, Siti Zuhro mengemukakan, di negara yang sudah maju, pergantian atau suksesi kepemimpinan berlangsung dari bawah (bottom up). Seleksi dimulai dari bawah sampai mencapai jenjang karier tertinggi.

Kesempatan untuk naik jenjang dalam sistem karier dinamakan sebagai promosi naik jabatan. Promosi jabatan adalah perpindahan dari suatu jabatan ke jabatan lain yang mempunyai status dan tanggung 
jawab yang lebih tinggi (Martoyo, 2007:71).

Pola promosi Jabatan ini telah diterapkan di lingkungan Pegawai Negeri Sipil, sebagaimana di muat dalam Undang-Undang No. 05 Tahun 2014 tentang Aparatur Sipil Negara, Pasal 72; ayat (1) Promosi PNS dilakukan berdasarkan perbandingan objektif antara kompetensi, kualifikasi, dan persyaratan yang dibutuhkan oleh jabatan, penilaian atas prestasi kerja, kepemimpinan, kerja sama, kreativitas, dan pertimbangan dari tim penilai kinerja PNS pada Instansi Pemerintah, tanpa membedakan jender, suku, agama, ras, dan golongan. (2) Setiap PNS yang memenuhi syarat mempunyai hak yang sama untuk dipromosikan ke jenjang jabatan yang lebih tinggi.

Penulis melihat sistem karir berjenjang juga sangat cocok untuk diterapkan dalam sistem seleksi kepemimpinan nasional. Sistem karier berjenjang akan memastikan dapat berjalannya proses kaderisasi, secara natural kader-kader berpengalaman telah dipersiapkan untuk melanjutkan tongkat estafet kepemimpinan. Donald (2007) mengatakan bahwa keberhasilan suatu organisasi ditentukan oleh individu yang memiliki kompetensi. Menilai kompetensi individu dilihat dari empat sisi yaitu pengetahuan, keterampilan, pengalaman dan sikap penguasaan kerja.

Para pemimpin-pemimpin daerah yang berprestasi/berhasil memimpin daerah, tidak cukup hanya diberikan penghargaan berupa "autonomy award" atau penghargaan-penghargaan yang serupa. Tetapi sudah saatnya bagi mereka yang berhasil ini didorong untuk menyiapkan diri memimpin negeri. Melalui mekanisme ini calon pemimpin yang akan menduduki skala kepemimpinan tertentu memiliki track record yang jelas dan dapat diketahui oleh publik. Selanjutnya, akan dibahas bagaimana proses suksesi kepemimpinan nasional berdasarkan Pancasila dapat diterapkan secara selektif berjenjang ini mulai dari level yang paling bawah sampai dengan level yang tertinggi di negeri ini.

\section{Implementasi \\ Suksesi kepemimpinan Nasional berdasarkan Pancasila Secara Selektif Berjenjang dari tingkat RT sampai Presiden}

Bangsa Indonesia adalah sekelompok masyarakat Indonesia yang bersatu atau dipersatukan karena adanya persamaan sejarah dan nasib, serta memiliki cita-cita yang sama untuk kehidupan di masa yang akan datang. Sejarah Indonesia telah meliputi suatu rentang waktu yang sangat panjang. Sejak awal kemerdekaan, pasca proklamasi kemerdekaan (1945), sampai jatuhnya Soekarno (1966), era orde baru, 32 tahun masa pemerintahan Soeharto (1966-1998), serta era reformasi yang berlangsung sampai sekarang, Indonesia telah mengalami pasang-surut, tragedi dan berbagai pengalaman berharga. Namun melihat perkembangan dinamika politik saat ini, cukup membuat kita merasa miris, setiap kali musim pemilu, perebutan kekuasaan terlihat sangat vulgar, suasana sosial terasa menjadi panas, masyarakat seolah-olah terbelah sesuai dukungan masing-masing, bahkan 
gesekan politik ini dapat berkembang menjadi isu SARA.

Keadaan yang demikian sangat rawan untuk keutuhan NKRI dalam jangka panjang. Sebelum segalanya terlambat, bangsa kita harus mulai berbenah, bangsa Indonesia harus mulai sadar dengan jati dirinya sebagai negara yang berbudaya luhur. Sudah saatnya masyarakat mulai menyatukan diri dalam semangat gotongroyong. Semua perbedaan kelompok perlu bersatu di bawah Pancasila sebagai cara pandang bersama terutama dalam urusan politik, pembagian dan penentuan pemegang kepimpinan nasional di negeri ini.

BS. Kepemimpinan Modul 1, Sub BS. Lemhanas RI, Jakarta, hal 7 menyebutkan Pengertian kepemimpinan Nasional adalah kelompok pemimpin bangsa pada segenap strata kehidupan nasional didalam setiap gatra (Asta Gatra) pada bidang/sektor profesi baik di supra struktur, infra struktur dan sub struktur, formal dan informal yang memilki kemampuan dan kewenangan untuk mengarahkan/mengerahkan kehidupan nasional (bangsa dan negara) dalam rangka pencapaian tujuan nasional berdasarkan Pancasila dan UUD 1945.

Sedangkan pembahasan dalam artikel ini dibatasi pada kepemimpinan pemegang jenjang wilayah di Indonesia, mulai level Desa sampai dengan Pusat, yakni: RT (Rukun Tetengga), RW (Rukun Warga), Kepala Desa/Lurah, Camat, Bupati/Wali Kota/Gubernur, dan Presiden. Bagaimana mencipatkan sistem suksesi kepemimpinan semua jenjang tersebut secara efektif dan efisien?
Mari kita lihat bagaimana hal ini bisa dimungkinkan. Kita bisa membuat mekanisme seleksi kepemimpinan dengan asas musyawarah mufakat sebagaimana amanat ideologi bangsa Pancasila, dimulai dari tingkat kepemimpinan paling dasar, yakni ketua RT terus berlanjut secara selektif sampai jenjang sampai yang paling tinggi yakni Presiden. Sistem peningkatan jenjang kepemimpinan ini menganut prinsip setiap yang dilihat paling baik dalam memimpin satu jenjang wilayah, dialah yang paling berhak dipilih untuk menjadi pemimpin pada jenjang wilayah selanjutnya.

Sebagai tahap awal, bangsa kita bisa menyelenggarakan pemilihan Ketua RT secara serentak di seluruh Indonesia. Pemilihan ketua RT secara serentak inilah tonggak awal dimulainya sistem pemilihan para pemimpin yang baru. Pemilihan Ketua RT secara serentak ini akan menjadi terasa istimewa bagi rakyat, dan akan mendorong rakyat utuk memilih sosok yang terbaik, karena masyarakat paham Ketua RT yang mereka pilih kelak adalah calon Presiden NKRI.

Mekanismenya adalah warga masyarakat di lingkungan setingkat RT bermusyawarah untuk mencalonkan untuk kemudian memilih siapa diantara mereka yang dipandang paling dapat dipercaya, bijaksana, serta cakap untuk diangkat sebagai ketua RT. Kemudian untuk mengisi jenjang selanjutnya pada tingkat RW, sistem seleksi berjenjang mulai diterapkan, para Ketua RT dalam lingkungan RW tersebut bermusyawarah bersama perwakilan masyarakat menentukan siapa diantara mereka yang 
paling nyata memberikan kontribusi kebaikan bagi warga, untuk kemudian diangkat bersama-sama sebagai Ketua RW. Demikian selanjutnya untuk jenjang Kepala Desa berlaku mekanisme yang sama, berdasarkan musyawarah mufakat dilakukan pemilihan Ketua RW terbaik untuk diangkat bersama-sama sebagai Kepala Desa.

Berlaku seterusnya Kepala Desa yang terbaik untuk diangkat sebagai Camat. Demikian juga dalam proses pemilihan Bupati, dan pemilihan Gubernur, sampai pada tahap yang Presiden RI. Memandangn tata cara pemilihan sebagaimana diuraikan di atas maka pada akhirnya jabatan Presiden pun mengikuti jenjang karier dari RT. Calon Presiden RI adalah para pemimpin yang telah berhasil melewati perjalanan panjang, putra/putri terbaik bangsa utusan dari 34 Provinsi yang ada di Indonesia.

Dari pola ini kita bisa melihat bahwa kenaikan pangkat dari RT, menuju RW dan kemudian Kepala Desa, dan seterusnya adalah mekanisme yang jelas. Para calon pemimpin dapat dilihat rekam jejak dan kualitasnya secara langsung semasa bertugas. Mereka yang akan naik terus ke atas dari level RT sampai Kabupaten saja melalui mekanisme ini telah dapat dikatakan benar-benar manusia pilihan. Seseorang yang kapabiltas kepemimpinan yang bisa menginspirasi secara mendalam di sebuah Kabupaten atau Kota pasti memiliki bakat dan panggilan jiwa yang kuat sebagai anugrah yang diberikan oleh Tuhan Yang Maha Kuasa.
Apalagi mereka yang dapat naik sebagai Gubernur, sampai jenjang terakhir yakni, Presiden. Bayangkan Presiden RI adalah satu orang yang memiliki sejarah sebagai Ketua RT hasil ayakan dari 8.490 kelurahan, dan 74.957 Desa yang ada di Indonesia. Seseorang yang mampu mencapai puncak tanpa tersangkut persoalan hukum. Selain memiliki kepandaian dan kecakapan di atas ratarata, dirinya juga sosok teladan yang ketulusan dan budi pekerti yang tinggi disertai kemampuan berkomunikasi dan menggerakan rakyat secara mumpuni.

Tidak ada perwakilan yang terbaik untuk menduduki jenjang kepemimpinan yang lebih tinggi kecuali orang-orang yang telah memiliki pengalaman pada jenjang kepemimpinan sebelumnya. Kelebihan selanjutnya mekanisme ini adalah politik berbiaya murah, baik dari sisi para calon pemimpin dan penyelenggaraan. Melalui mekanisme ini juga maka Kepala Desa, Bupati/Wali Kota, Gubernur benar-benar mewakili daerah/tanahnya. Hal ini akan menghindarkan dari sentimen chauvinisme dan kecemburan putra asli tiap daerah.

Mengapa untuk memilih para pemimpin wilayah di Indonesia perlu dimulai dari jenjang yang paling bawah, yakni pada tingkat RT. Karena pada level wilayah inilah semua masyarakat masih saling mengenal satu sama lain secara intensif. Seseorang yang akan dicalonkan sebagai pemimpin dapat dikenal secara langsung kecerdasan, kecakapan dan budi pekertinya dalam perilaku sehari-hari. Pada semua jenjang kepemimpinan wilayah di Indonesia, jabatan Ketua RTlah yang masih relatif murni sebagai 
panggilan pengabdian, peran dan tanggungjawabnya langsung bersentuhan dengan masyarakat, namun penghasilan dari Ketua RT tidak seberapa.

Ketua RT adalah pekerjaan pengorbanan yang sangat minim imbalan, biarlah keadaan dipertahankan tetap demikian. Secara tidak langsung maka dapat dipastikan hanya orang-orang yang memiliki semangat perjuangan dan ketulusan yang bersedia menjadi Ketua RT. Selain itu calon Ketua RT dipersyaratkan adalah seorang pemuda atau bahkan remaja. Mengapa, karena selain dipersiapkan sebagai bibit pemimpin bangsa ke depan, dirinya juga akan menginspirasi para pemuda dan remaja di setiap wilayah, bahwa golongan mereka diapresiasi dan diberi kedudukan terhormat untuk berkiprah di dalam mayarakat. Seorang pemuda juga masih memiliki energi yang melimpah, serta idealisme yang tinggi.

Terkait teknis mekanisme pemilihan dapat diatur lebih lanjut, antara lain: penentuan indikator calon yang layak masuk dalam bursa pemilihan, teknis pemaparan program dan adu gagasan antar calon, dll. Perwakilan BPD, DRPD Kabupaten/Kota, DPRD Provinsi, dan DPR RI/MPR sebagai representasi rakyat turut dilibatkan dalam proses pemilihan pemimpin sesuai dengan jenjangnya. Keberadaan KPU dapat bertindak sebagai panitia penyelenggara pemilihan. Sedangkan Bawaslu bertindak sebagai pengawas dalam proses pemilihan tersebut.

Mengikuti pola di atas maka secara bertahap seluruh jenjang kepimpinan dari level paling bawah sampai jenjang paling tinggi akan terisi para pemimpinpemimpin teladan. Setelah masa jabatan selesai, pemilihan setiap jenjang jabatan dilakukan kembali. Demikian uraian tentang gagasan suksesi kepemimpinan nasional berdasarkan Pancasila secara selektif berjenjang. Sistem yang sama juga dapat diterapkan dalam pemilihan Dewan Perwakilan rakyat (legislatif) semua jenjang dari tingkat Desa sampai Pusat.

\section{Kesimpulan}

Berbagai Kelebihan mekanisme sebagaimana telah diuraikan dalam pembahasan di atas adalah jawaban atas berbagai kelemahan dan persoalan perpolitikan yang terjadi saat ini. Mekanisme suksesi kepemimpinan menjadi efisien karena biaya politik yang mahal menjadi sangat murah, para calon pemimpin tidak akan lagi membutuhkan dana besar untuk keperluan "mahar" dan kampanye. Keadaan tersebut juga secara langsung akan meminimalisir timbulnya perilaku koruptif.

Kelebihan mekanisme suksesi kepemimpinan berjenjang ini juga akan lebih efektif melahirkan para pemimpin yang mumpuni. Para pemimpin yang terpilih memiliki track record yang jelas, kualitas teruji secara nyata di lapangan. Melalui mekanisme selektif berjenjang ini tidak ada lagi istilah memilih kucing dalam karung, tidak akan ada lagi Kepala Daerah yang hanya mengandalkan popularitas dan modal kekayaan duduk sebagai wali kota/Bupati atau Gubernur.

Melalui sistem kepimpinan yang bertumbuh ini juga akan berimplikasi 
pada demokratisasi yang kondusif, melalui musyawarah mufakat dan keterwakilan rakyat maka perpecahan dan konflik sosial yang tajam tidak terjadi. Semoga gagasan ini dapat menjadi pertimbangan bagi pejabat pembuat undang-undang untuk melakukan legislative review terhadap Undang-undang nomor 10/2016 tantang pemilihan gubernur, bupati dan wali kota serta, undang-undang nomor 07/2017 tentang pemilihan umum.

Selanjutnya, demi kemajuan dan kebaikan negeri tercinta, gagasan suksesi kepemimpinan nasional secara selektif berjenjang dari tingkat RT sampai presiden ini perlu dipertimbangkan oleh para pengambil kebijakan dan seluruh rakyat Indonesia sebagai bahan kajian dan selanjutnya dapat diimplementasikan Indonesia.

\section{Referensi}

Badu, S. Q. \& Djafri, N. (2017). Kepemimpinan dan Perilaku Organisasi. Gorontalo: Ideas Publhising.

Darmodiharjo, D. (2010). Menatap Indonesia, Sebuah Antologi Filsafat Hukum dalam Bingkai Negara Pancasila. Bandung: Jendela Mas Pustaka.

Handoko, T. H. (2000). Manajemen Sumber Daya Manusia. Yogyakarta: BPFE.

Ini yang Mendorong Kepala Daerah Korupsi Menurut Pengamat Republika Online. (n.d.). Retrieved 15 February 2019, from https://www.republika.co.id/berita/n asional/hukum/18/02/20/p4ew5h35 4-ini-yang-mendorong-kepala-daerahkorupsi-menurut-pengamat
Kemenristekdikti. (2016). Buku Mata Ajar Kuliah Wajib Umum Pendidikan Kewarganegaraan untuk Perguruan Tinggi. Jakarta: Direktorat Jenderal Pembelajaran dan Kemahasiswaan.

Kompasiana.com. (n.d.). 700-an

Pemimpin di 2019. Retrieved 13 February 2019, from KOMPASIANA website:

https://www.kompasiana.com/aryand i/58cf8374729373290f5c98d5/700an-pemimpin-di-2019

Martoyo, S. (1998). Manajemen Sumber Daya Manusia. Yogyakarta: BPFE.

Marwansyah. (2010). Manajemen Sumber Daya Manusia. Bandung: Alfabeta.

Memilih Pemimpin Tanpa Partai oleh Aryandi Yogaswara Halaman all Kompasiana.com. (n.d.). Retrieved 10 February 2019, from https://www.kompasiana.com/aryand i/58ce04136ea83458048b456a/memil ih-pemimpin-tanpa-partai? page $=$ all

Pokja Kepemimpinan Lembaga Ketahanan Nasional. (2011). BS. Kepemimpinan Modul 1, Sub BS. Kepemimpinan Nasional. Jakarta: Lemhanas RI.

Politik Biaya Tinggi jadi Pintu Masuk Korupsi. (n.d.). Retrieved 13 February 2019, from https://mediaindonesia.com/read/det ail/202007-politik-biaya-tinggi-jadipintu-masuk-korupsi.html

Prastowo, A. (2012). Metode Penelitian Kualitatif dalam Perspektif Rancangan Penelitian. Yogyakarta: Ar-ruzzmedia.

Siagian, S. P. (2019) Kiat Meningkatkan Produktifitas Kerja. Jakarta: PT Rineka Cipta. 
Jurnal Pendidikan Kewarganegaraan

Vol. 6 No. 1 Maret 2019

Simamora, H. (1999). Manajemen Sumber Daya Manusia, Edisi ke-2, Cetakan. Kedua. Yogyakarta: STIE YKPN.

Tim Pengembang Ilmu Pendidikan. (2007). Ilmu dan Aplikasi Pendidikan. Bandung: PT. Imtima.

Tim Penyusun Kamus Pusat Bahasa. (2001). Kamus Besar Bahasa Indonesia. Jakarta: Departemen Pendidikan Nasional.

Undang-Undang Nomor 05 Tahun 2014 tentang Aparatur Sipil Negara.
Journal of Civics and Education Studies p-ISSN 2302-0865 | e-ISSN 2621-346X

Zuhro, R. S. (2009). Demokrasi Lokal: Peran Aktor dalam Demokratisasi. Yogyakarta: Ombak.

Pemilu Indonesia Paling Rumit di Dunia | Koran Jakarta. (n.d.). Retrieved 10 February 2019, from http://www.koranjakarta.com/pemilu-indonesia-palingrumit-di-dunia/ 